\title{
VIABILITY AND GLYCOGEN RESERVES IN THE NEWLY LIBERATED LARVAE OF OSTREA EDULIS L.
}

\author{
By Dorothy M. Collyer \\ Fisheries Laboratory, Burnham-on-Crouch, Essex
}

It has been suspected that broods of larvae of the European flat oyster, Ostrea edulis L., differ considerably in their vigour and in the ease with which they can be reared in the laboratory (Cole, 1939; Bruce, Knight \& Parke, 1940; Walne, 1956). The discovery of the cause of this phenomenon would be a step forward in breeding experiments, and might possibly indicate a way in which the vigour of larvae could be improved. It was thought that a possible explanation might be differences in the glycogen reserves in the larvae at the time of liberation, and for this reason the series of analyses reported in this paper were made.

\section{Method}

Twelve broods of larvae were obtained from oysters kept in running sea water at the Conway laboratory. A sample of each brood, in most cases between 100,000 and 200,000 larvae, was washed with distilled water, dried and preserved for glycogen assay. The remainder of the brood was reared by Mr P. R. Walne at Conway by his standard technique (Walne, 1956). Briefly, this method involves placing about rooo larvae in I 1. of filtered sea water in a glass vessel, which is stood in a water bath at $20-22^{\circ} \mathrm{C}$. The larvae are kept stirred by gentle aeration, and in these experiments were fed with cultures of the flagellate Isochrysis galbana, the density of which was kept at about 50 cells per $\mathrm{mm}^{3}$. When eyed larvae were first observed collectors in the form of mussel shells or broken unglazed saucers were added. When all the larvae had either metamorphosed on collectors or were clearly moribund, the experiment was concluded and the number of metamorphosed larvae counted. The twelve broods which were tested gave a considerable range of results, the percentage of larvae metamorphosing ranging from 0 to 25 .

It was desirable to be able to express the glycogen content as a percentage of organic matter, so as to eliminate differences due to the relative proportion of weight represented by the physiologically inert calcareous shell. The following procedure fulfilled this requirement, and at the same time eliminated errors due to sea-salt contamination. To each sample of larvae $\mathrm{I} \cdot 2 \mathrm{~N}$ hydrochloric acid was added drop by drop until no more effervescence occurred and a slight excess of acid was present. The acid suspension was 
transferred to the central compartment of a Perspex electrodialyser, the basis of which were Permutit ion-exchange membranes 'Permaplex' A-Io and C-Io. This apparatus was similar to that described by Blainey \& Yardley (1956), differing in that an iron cathode and a carbon anode were used; and instead of acid and alkali respectively in the electrode compartments, a continuous flow of tap water removed the products of electrolysis. The dialyser was connected to a I $2 \mathrm{~V}$ battery overnight. Preliminary tests showed this to demineralize such a solution beyond the limits of weighing, but an $8 \mathrm{~h}$ period was insufficient. Leakage of solution from the compartment could be prevented by the careful use of vaseline on the Perspex surfaces gripping the membranes.

The suspension was transferred to a tared tube and dried at $105^{\circ} \mathrm{C}$ to constant weight, which ranged in the samples from 25 to $90 \mathrm{mg}$. Hydrolysis of glycogen was carried out in the same tube, Io $\mathrm{ml}$. of $3 \%(\mathrm{v} / \mathrm{v})$ sulphuric acid being added. The tubes were immersed in a boiling-water bath for $3 \mathrm{~h}$, and early in this operation the dried material was shaken into a good suspension in the acid. The samples were neutralized, filtered, and, with rinsings, made up to either $100 \mathrm{ml}$. or $25 \mathrm{ml}$. according to the weight available. Duplicate ro $\mathrm{ml}$. aliquots were taken, and reducing sugars determined according to the Hagedorn-Jensen method as modified by Hulme \& Narain (I93I).

\section{TABLE 1. PARTICULARS OF OYSTER LARVAE}

The date of liberation, parentage, size and glycogen content of twelve broods of oyster larvae collected at Conway in I955. The parent stock were all brought in from the oysterage on 9 July. The 'Conway' oysters were 3-year-old oysters bred in the Conway tanks. The 'Brittany' oysters were imported from France in I954 and relaid in the Tal-y-foel oysterage. The larval size is expressed as the percentage in each size category, the length of the shell being the dimension measured. The actual number of spat obtained in each experiment is shown and this number is also expressed as a percentage of the initial number of larvae in the experiment. The final column gives the glucose found expressed as a percentage of the dry organic matter (to convert to glycogen multiply by 0.927).

\begin{tabular}{|c|c|c|c|c|c|c|c|c|c|}
\hline \multirow[b]{2}{*}{$\begin{array}{c}\text { Date } \\
\text { of } \\
\text { liberation }\end{array}$} & \multirow[b]{2}{*}{ Oyster } & \multicolumn{6}{|c|}{$\begin{array}{c}\text { Percentage size distribution of larvae } \\
\text { at liberation }(\mu)\end{array}$} & \multirow[b]{2}{*}{$\begin{array}{l}\text { Number } \\
\text { of } \\
\text { spat }\end{array}$} & \multirow[b]{2}{*}{$\underset{(\%)}{\text { Glucose }}$} \\
\hline & & $\begin{array}{c}\text { I50- } \\
\text { I59 }\end{array}$ & $\begin{array}{l}160- \\
169\end{array}$ & $\begin{array}{r}170- \\
179\end{array}$ & $\begin{array}{l}180- \\
189\end{array}$ & $\begin{array}{l}\text { 190- } \\
\text { 199 }\end{array}$ & $\begin{array}{c}200- \\
209\end{array}$ & & \\
\hline I6 July & Conway & - & - & 4 & 52 & 28 & I6 & 0 & 15.7 \\
\hline 20 & Conway & 8 & 28 & 40 & 24 & - & - & 0 & 15.0 \\
\hline 25 & Conway & - & 8 & 52 & 40 & - & - & 0 & 16.6 \\
\hline 26 & Brittany & - & 32 & 40 & 20 & 8 & - & 0 & $15 \cdot 8$ \\
\hline 27 & Brittany & - & - & 28 & 72 & - & - & I34 (25\%) & 15.8 \\
\hline 29 & Brittany & - & 32 & 56 & 12 & - & - & o & $16 \cdot 6$ \\
\hline 30 & Brittany & 一 & 4 & 44 & 48 & 4 & - & $42(7 \%)$ & 14.9 \\
\hline 22 Aug. & Brittany & 4 & 4 & 40 & 52 & - & - & 0 & I 4.5 \\
\hline 23 & Conway & 4 & 72 & 20 & 4 & - & - & $139(17 \%)$ & $15 \cdot 3$ \\
\hline 23 & Conway & 56 & 44 & - & -7 & - & - & $33(5 \%)$ & 16.0 \\
\hline 24 & Brittany & 4 & 36 & 52 & 8 & - & - & 0 & 15.7 \\
\hline 25 & Brittany & 4 & 44 & 48 & 4 & - & - & ० & I5. I \\
\hline
\end{tabular}




\section{Conclusion}

The amounts of glucose found, expressed as a percentage of organic matter, lay in all twelve cases between 14.5 and I6.6 (equivalent to 13.4 and $15.4 \%$ glycogen). The details are shown in Table $\mathrm{I}$. In view of such very small differences in glycogen reserves, it was concluded that some other factor must be responsible for the large viability differences observed. Certainly no correlation can be observed between the glycogen reserves and either the size of the larvae at liberation or the yield of spat.

\section{SUMMARY}

Samples of twelve broods of oyster larvae were subjected to a standard laboratory rearing technique while other samples were assayed for glycogen. The glycogen reserves of the larvae at liberation lay between 13.4 and $15.4 \%$ of the dry organic matter. No correlation was observed between the glycogen reserve and either the size of the larvae at liberation or the yield of spat in the rearing experiments.

\section{REFERENCES}

Blainey, J. D. \& YARDLEY, H. J., 1956. Electrolytic desalting with ion-exchange membranes. Nature, Lond., Vol. I77, p. 83.

BRUCE, J. R., KNIGHT, M. \& PARKE, M. W., I940. The rearing of oyster larvae on an algal diet. F. mar. biol. Ass. U.K., Vol. 24, pp. 337-74.

Cole, H. A., 1939. Further experiments in the breeding of oysters (Ostrea edulis) in tanks. Fish. Invest., Lond., Ser. 2, Vol. I6, No. 4.

Hulme, A. C. \& Narain, R., I93I. The ferricyanide method for the determination of reducing sugars. A modification of the Hagedorn-Jensen-Hanes technique. Biochem. F., Vol. 25, pp. I05I-6I.

WALNE, P. R., I956. Experiments on rearing the larvae of Ostrea edulis L. in the laboratory. Fish. Invest., Lond., Ser. 2, Vol. 20, No. 9. 